Linguistik Terapan 14 (2) (2017): 110-121

Jurnal Linguistik Terapan Pascasarjana

Available online

http://jurnal.unimed.ac.id/2017/index.php/JLT-Unimed

\title{
LANGUAGE SHIFT AND MAINTENANCE OF INTERMARRIAGES CHINESE FAMILIES
}

\section{MAIRTATI DEWI}

Sumarsih

\section{Anni Holila Pulungan}

Linguistik Terapan Bahasa Inggris

Diterima Agustus 2017; Disetujui Oktober 2017; Dipublikasikan Desember 2017

\begin{abstract}
This study deals with language shift and language maintenance of intermarriages Chinese families.It aims at finding out the factors make language shift and language maintenance occur, finding out how language shift and language maintain occur and finding out why language shift and language maintain occur.This study was conducted in qualitative method.The sources of data were four intermarriage Chinese families; meanwhile the data was their utterances.The data was analyzed by using Interactive Model by Miles, Huberman, and Saldana. To find out what factors affecting language shift and maintenance, the researcher used Holmes's theory. Based on the data analysis, the first finding shows that there were six factors affecting language shift and language maintenance occured in intermarriage chinese families namely bilingualism, migration, economic, environment, demographic, and attitude. And as the second finding was that the language shift and language maintenance occured since there are two languages exist in interethnic marriage. The existence of two languages means the competition between two languages. And as the third finding was the reasons why language shift and language maintenance occured are bilingualism in which the man or woman mastered two languages which led to language maintenance, migration in which the women migrate to follow their husband, economic factor dealing with the men and women's occupations, environment where they lived in homogenous or heterogenous ethnic, demographic factor, and attitude which might be postive or negative.
\end{abstract}

Keywords: language shift, maintenance, intermarriage, qualitative

How to Cite: Dewi, Mairtati (2017).

Language Shift and Maintenance of Intermarriages Chinese Families. Jurnal Linguistik

Terapan Pascasarjana Unimed, 14 (2): 110-121. 


\section{INTRODUCTION}

All human activities always involve language as a means to interact among people. Indonesia consists of many ethnics and languages. So, there is a tendency that inter-ethnic marriages happens. Inter-ethnic marriage are a combination of two people from different ethnic and language also. It means that there are two languages exist in interethnic marriage couple. The existence of two languages means the competition between two language. So the researcher is interested in investigating this phenomenon especially in Chinese family in Kilometre 12 Medan. The researcher found the language shift and language maintaince that happened in inter marriage of chinese family. Fasold (1984:231) states that language shift refers to changes in language use among a community of speakers. Weinreich (1978:79) states similarly as Fasold, he defines language shift as the changes from the habitual use of one language to another.

Chinese Indonesian account for about 3\% of the population but they are influential, controlling most of the country's wealth and commerce. Many vernaculars in Indonesia shifted even endangered. As it was informed in Kompas (2007) about 726 of 746 vernaculars in Indonesia are endangered. Only 13 vernaculars have more than one million language users. Speaking about Chinese -Indonesians are ethnic Chinese people living in Indonesia, as a result of centuries of overseas Chinese migration. The Chinese-Indonesian experience in Indonesia is one of extremes. On the one hand, they have made it their home and it's been a land of plenty as many have become fabulously rich, mostly in business. On the other hand, there have been some bloody pogroms targeting them, the most recent in 1998. Official discrimination is still on the books (or, at least, implemented as such) in most government offices.

Currently, there are roughly nine million Chinese-Indonesians spread throughout the archipelago, mostly in large urban centers. There are approximately three million ChineseIndonesians in Greater Jakarta and despite being a tiny minority of the overall ethnic makeup of Indonesia (less than 4 percent of the total), their enormous economic strength and concentration in the capital city means the Chinese-Indonesian "footprint" is ubiquitous in many sectors. Speaking about one of the ethnic groups is chinese. Chinese: The most significant ethnic minority of foreign origin in Indonesia. Chinese began inhabiting Indonesia since the 15th century with significant waves in 18th and 19th century. Mostly concentrated in pecinan (chinatowns) in urban Java, Sumatra and Kalimantan cities with significant numbers in Jakarta, North Sumatra, Riau, Riau Islands, BangkaBelitung Islands, and West Kalimantan. Since Indonesian independence, the Javanese and Bataknese have replaced the Chinese as the largest ethnic group in Medan in 2000 census: A highly visible component of Medan's population is the large number of Chinese, the largest Chinese community on Sumatra Island, who are active in the business and trading sector. Almost all Chinese residents in 
Medan can speak fluent Hokkien, a dialect originating from Fujian Province in Southern China. Medan also has its own variation of Hokkien, known as Medan Hokkien the Chinese living spread throughout the city.

The researcher in this study found it is important to conduct a study on Chinese language shift and language maintaince in mixed married families.In Medan, Chinese people socialized with many people who are from other ethnics. In this case, a man from Chinese is looking for a no Chinese woman or a Chinese woman is looking for a non Chinese man then they got married with. We classified their family into intermarriage families because they are different ethnic and culture. It is aimed to find out whether the intermarriage chinese families maintain or shift the language.

\section{RESEARCH METHODOLOGY}

This study was conducted in qualitative reseach design. According to Guba and Wolf in Bogdan \& Biklen (1982) qualitative reseach is called naturalistic because the reseacher frequents places where the events he or she is interested in natural occur. And the data were gathered by interview, questionnaire and observation.

Bogdan and Biklen (1982) state that qualitative reseach is descriptive. The data colected were in the form of words. The data included observation sheets and questionnaire documents. This study described what factors affected language shift and language maintenance occured in intermarriage Chinese families, how the language shift and language maintenance occured in intermarriage Chinese families, and the reasons why language shift and language maintenance occured in intermarriage Chinese families.

The data of this study were the utterances of the intermarriage chinese families. The utterances for each respondents were $10-15$ utterences. The source of data were four intermarriage Chinese families. They were selected based on the family background. The source of data classification based on intermarriage family could be seen on the following table.

Table 1. Subject classification based on intermarriage families

\begin{tabular}{ccc}
\hline $\begin{array}{c}\text { Intermarriage Chinese } \\
\text { Families }\end{array}$ & Man & Woman \\
\hline $\mathrm{CM}-\mathrm{BW}$ & Chinese & Bataknese \\
\hline $\mathrm{CM}-\mathrm{MW}$ & Chinese & Malaynese \\
\hline $\mathrm{AM}-\mathrm{CW}$ & Acehnese & Chinese \\
\hline $\mathrm{JM}-\mathrm{CW}$ & Javanese & Chinese
\end{tabular}

Notes:

CM : Chinese Men

BW : Bataknese Woman

MW : Malaynese Woman

AM : Acehnese Man

JW : Javanese Woman 
As known that one of characteristics of qualitative research was the research has the natural setting as the direct soure of data and the researcher is the key instrument Bogdan \& Biglen, 1992:29). Therefore, as the main instrument of this study was the researcher. Here, the researcher touched down the field of the study directly in order to conduct the observation. The secondary instrument which were used by the researcher were questionnaire.

In qualitative analysis, the data concerned appear in words rather than in numbers. They might have been collected in a variety of ways (observation, interviews, tape recording), and are usually "processed" somewhat before they are ready for use (via dictation, typing up, editing, or transcription), but they remain words, usually organized into extended text (Miles and Huberman). To analyze the data that had been gathered, the researcher used four steps from Miles, Huberman, and Saldana (2014), they are data collection, data condensation, data display, and data conclusion. Look at the figure below, it showed the process from the first into the last step.

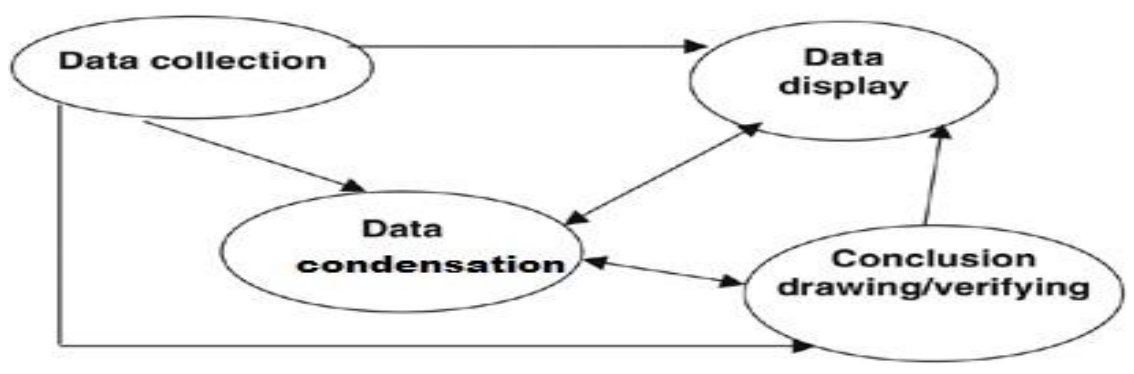

Figure 1 Components of Data

Analysis: Interactive Model taken from Miles, Huberman, and Saldana (2014)

Based on the statements and the picture above, after the data had been collected, it was analyzed in four steps, they were:

1. Data collection

Data collection is process of collecting the data. Data collection suggested by Bogdan and Biklen (2014) was done by questionnaire, interview, and participant observation. In this research those insruments were used to collect the data. Questionnaire was used to find out how the language can be maintened and shifted. Meanwhile, participant observation was done by recording family to find out the utterances that they used.

2. Data condensation

There were many data that had been collected in the data collection. Data condensation refers to the process of selecting, focusing, simplifying, abstracting, and/or transforming the data that appear in the full body (corpus) of written up field notes, interview, transcripts, documents, and other empirical materials. By condensing, the data will be stronger and easier to analyze.

a. Selecting 
Selecting meant the researcher selected the appropriate data related to this study. In line with this study, the researcher chose clear questionnaire sheet that had been answered by the chinese family.

b. Focusing

Focusing meant the researcher paid attention to the appropriate data. In this study, the researcher focused on utterance of family in daily activity.

c. Simplifying

Simplifying helped the researcher to simplify the data. The data were collected need to be simplified so the researcher was easy to analyze it.

d. Abstracting

Abstracting meant summarized the data. In this step, the researcher compared descriptions of family utterances in language maintenance or language shift.

e. Transforming

In this last step, the researcher tranformed the description of chinese family that shifted and maintened their languages.

\section{Data display}

Miles, Huberman, and Saldana (2014) argue that data display refers to a group of information which can be used as the guidance for the researchers to make a conclusion and as the base to take a further action. Generally, the utterances that were condensed were displayed.

\section{Drawing conclusions/verification}

The data were concluded and verified after reducing and displaying it. All the data that had been collected on the observation, recording and interview needed to be verified before the researcher took the final conclusion. The raw conclusion also needed to be verified. In this case, if the researcher found the new data, the raw conclusion needed to be changed, but if there was no other data, the researcher could take a final conclusion of the research. In line with this study, the conclusion was taken by describing all the tables displayed in depth.

In qualitative research the analyzed data must be trustworthy through checking that the interpretations are credibility, transferability, dependability, and conformability. Lincoln and Guba (1985) describe trustworthiness as the truth value of the findings of the study.

\section{Credibility}

Credibility is confidence in the 'truth' of the findings. To make the research credible, the research use triangulation technique. According to Den (1970) there are four basic types of triangulation as follows:

a. Methodological triangulation, which refers to the use of more than one method for gathering data. 
b. Investigator triangulation, which refers to the use of more than one researcher in the field to gather and interpret data. It involves the use of multiple observers, interviewers or data analysis in the same study for confirmation purposes.

c. Theoretical triangulation, which refers to the use of more than one theoretical position in interpreting data.

d. Data triangulation, which entails gathering data through several sampling strategies, so that slices of data at different times and social situations, as well as son a variety of people, are gathered.

Thus, the researcher used methodological triangulation, theoretical triangulation and data triangulation in this study. Methodological triangulation was gained from observation and documentation. Theoretical triangulation was conducted by checking data with some theories provided by the scholars. Data triangulation was gained from the the students' utterances

\section{Transferability}

Transferability is showing that the findings have applicability in other contexts. The applicability was done by providing the detailed description or displaying comprehensive description of both process and the result of the research. The function was to enable the readers in evaluating the extent to which the conclusion drawn are transferable to other times, setting, situation, and people. The finding in this research could be transferred to a different setting or can be applied in the receiving context.

\section{Dependability}

Dependability is showing that the findings are consistent and could be repeated. The consistency of the findings is shown at the dependability. All the processes while conducting the research were reviewed by paying attention to the consistency and reliability of the data. To make sure that the data is dependable, the researcher deliberated checking and jotting down the process and result of the research. Therefore, similar results were gotten if another researcher did the same work, the same context, the same methods and the same participants.

\section{Conformability}

The idea of conformability is to enable the readers to determine how far the data and constructs emerging from it may be accepted. To make sure that the research was confirmable, the researcher made an audit trial which allows any observer to trace the course of the research step-bystep via the decisions made and procedures described. This process is called audit trail which is divided into two kinds: audit trail process and audit trail product. Therefore, the researcher deliberately jotted down the complete process of research which is done through observation, documentation. The audit trial consists of raw data, reduced data, and reconstructed data. This note was supported by some codes so the readers can easily go through the data. Some appendices were also attached to make the data confirmable. 


\section{FINDINGS AND DISCUSSIONS}

\section{Findings}

Based on the data collected through questionnaires in Appendix A, there were six factors affecting language shift and language maintenance occured in intermarriage chinese families namely bilingualism, migration, economic, environment, demographic, and attitude.

1. Bilingualism

It could be drawn that three intermarriage chinese families did language maintenance, they were Chinese Man - Bataknesenese Woman (CM - BW), Acehnesenese Man - Chinese Woman (AM - CW), Javanese Man - Chinese Woman (JM - CW); meanwhile one intermarriage Chinese families did language shift namely Chinese Man - Malaynesenese Woman (CM - MW).

\section{Migration}

The first intermarriage chinese families CM - BW, they lived in Medan or in other words the Bataknese Woman followed her husband to migrate to Medan area where is dominantly inhibeted by Chinese people. Therefore, they used to speaking Chinese language or we can categorize their language use as language maintenance. The next intermarriage Chinese families AM - CW lived in Medan which is dominantly inhibited by Chinese people as shown in data 2c, so they used Chinese language. We can categorize their language use as language maintenance.The last intermarriage Chinese families lived in Medan, they tend to use Chinese language at home because their family tend to migrate or visit woman families who use Chinese language as their spoken language in daily activities.

\section{Economic Factor}

Based on the table above, it could be drawn that economic factor only affected R1 in his language use. His profession as a manager requires him to use Chinese language which certainly affected his language use in daily life including at his home.

\section{Environment}

Environment was also one of crucial factor which affected language shift and language maintenance in intermarriage Chinese families. Based on the table above, it can be seen that R1 and R5 using Chinese language were influenced by environment. They socialized with Chinese people dominantly so they spoke Chinese language while gathering with friends.

\section{Demographic}

Demography as the living area also influenced the shifting of language in intermarriage chinese families. it could be drawn that actually the using of Indonesian language in mass media such as radio, TV, newspaper had a big role to affect the language used by intermarriage chinese families including parents and children. Furthermore, the rule of education in Indonesia to use 
Indonesian language in school also led the children to use Indonesian language with their teachers and their friends. It made them use Indonesian language dominantly rather than the vernacular language derived from their parents.

\section{Attitude}

Attitude towards the language was one of the vital factors influencing the language shift and language maintenance in intermarriage chinese families. It can be seen that R1, R5, R6, R7, and R9 had positive attitudes toward Chinese language since they use Chinese language in daily activities at home, therefore the did language maintenance. Meanwhile, R2,R3, R4, and R8 had negative attitudes toward their own languages. R2 is a Bataknese woman had negative attitude toward Bataknese language so she shifted her language into Chinese. R3 is a Malaynese woman also had negative attitude toward Malaynese language that is why she shifted her language into Indonesian language. R4 is a Malaynese man also had negative attitude toward Malaynese language that is why he shifted his language into Indonesian language. R8 is Javanese man also had negative attitude toward Javanese language that is why he shifted his language into Chinese and Indonesian language. their negaritive attitudes

The Occurences of Language Shift and Language Maintainance in Intermarriage Chinese Families in Medan

Indonesia consists of many ethnics and languages so there is a tendency that inter-ethnic marriages happens. In this case, Chinese is one of ethnics which lives in Indonesia. Chinese Indonesian account for about $3 \%$ of the population but they are influential, controlling most of the country's wealth and commerce. Chinese people tend to marry with other original ethnics from Indonesia which is called inter-ethnic marriage. Inter-ethnic marriage is a combination of two people from different ethnic and language also. It means that there are two languages exist in interethnic marriage couple. The existence of two languages means the competition between two language. The competition of two languages lead to language maintenance and language shift.

Table 2. The Occurances of Language Shift and Language Maintenance of Intermarriage Chinese Families in Medan

\begin{tabular}{|c|c|c|c|c|}
\hline \multirow{2}{*}{$\begin{array}{c}\text { Factors influencing } \\
\text { language shift and } \\
\text { language maintenance }\end{array}$} & \multicolumn{2}{|l|}{ Total of respondents (9 Respondents) } & \multicolumn{2}{l|}{ Percentage } \\
\cline { 2 - 5 } & Influenced & Not influenced & Influenced & $\begin{array}{c}\text { Not } \\
\text { influenced }\end{array}$ \\
\hline Bilingualism & 7 & 2 & 77.77 & 22.22 \\
\hline Migration & 3 & 6 & 33.33 & 66.66 \\
\hline Economic factor & 4 & 5 & 44.44 & 55.55 \\
\hline Environment & 2 & 7 & 22.22 & 77.77 \\
\hline Demographic & 9 & 0 & 100 & \\
\hline
\end{tabular}




\begin{tabular}{|l|l|l|l|l|l|}
\hline \multirow{2}{*}{ Attitude } & Positive & 5 & 4 & 55.55 & 44.44 \\
\cline { 2 - 6 } & Negative & 4 & 5 & 44.44 & 55.55 \\
\hline
\end{tabular}

\section{Discussion}

Based on the data analysis, it was found that inter-ethic marriages led the competition of two languages used by couple. This kind of competition ended by language maintenance or language shift. This phenomenon occured in intermarriage Chinese families with other three ethnics including Bataknese, Acehnese, Malaynese, and Javanese. It strengtehened the theory suggested by Romaine (2000:49) who says that shifting language is unavoidable when two languages compete for use in the same domain. But, language maintenance also occured due to certain social factors such as the participants, domains, the function and the topic of the interaction, social distance, the status relationship between people, features of the setting and the dimension of formality turn out to be important in accounting for language choice in many different of kinds of speech communities (Holmes, 1992).

In this research, it was found uniqueness in the phenomenon of language shift and language maintenance. In this case, of four intermarriage Chinese families, three did language maintenance and one did language shift. The three intermarriage Chinese families were Chinese Man - Batak Woman, Acehnese Man - Chinese Woman, Javanese man - Chinese Woman.

Factors which cause the speakers of a language maintain their language are various, those factors are attitude, value, identity, the policy of the government, economic pressure, social, and demographic factors. In this research, of all the factors argued by Fishman, there are six factors affecting language maintenance occured in those intermarriage Chinese families, they are bilingualism, migration, economic, environment, demographic, and attitude.

Language shift usually occurs in bilingualism or multilingualism community because of many factors such as bilingualism, migration, economic and social factor, political factors, demographic factors and also value and attitude of the language users. Language shift in this research occured on the marriage between Chinese man and Malaynese woman. This family lived in area where is inhibited by plural ethnic people, so they shifted their language become Indonesian language to communicate with others. It was also supported by both of them did not master their couple's vernacular language.

In line with the for phenomenon occured in intermarriage Chinese families, it could drawn that the role of woman as the mother in family highly affected the language use in family. It could be seen that the subjects of this research included two Chinese Men and two Chinese Women. In this case, both Chinese woman maintained Chinese language at their home. Their children used Chinese 
language. It could be seen from the third couple: Acehnese Man - Chinese Woman, and the fourth couple: Javanese man - Chinese Woman.

Meanwhile, for other two couples, the first couple was Chinese Man - Batak Woman, the Batak woman spoke Chinese fluently. She preferred to use Chinese in her work as a chef of Indonesian and Chinese food, even she was usually asked to make funeral tools needed by Chinese people. Her language use should be considered to see that mother's language affected children's language. The last case for the second couple: Chinese Man - Malaynese woman, in this situation, the Malaynese woman always spoke in Malay at home and at her working area. It affected her children not to use Chinese or malay, they finally used Indonesian language as the communication device. Based on the four phenomenon, it could be concluded that the close relation between woman and her children affected the language used by their children. Their children frequently imitated their mothers' language.

This study strengthened the findings of Namei (2012) who stated that the key to social and economic success is knowledge of majority language. It occured especially in the fir intermarriage couple. Batak woman mastered Chinese language as the majority language which truly led into the success of her career as a chef and seller funeral chinese properties.

\section{CONCLUSIONS}

Based on the data analysis, there are some valuable points that can be concluded, they are:

1. There were six factors affecting language shift and language maintenance occured in intermarriage chinese families namely bilingualism, migration, economic, environment, demographic, and attitude.

2. The language shift and language maintenance in intermarriage Chinese families occured since there are two languages exist in interethnic marriage couple. The existence of two languages means the competition between two languages. The competition of couple's languages in four intermarriage Chinese families led to language maintenance in three families namely Chinese Man - Batak Woman, Acehnese Man - Chinese Woman, Javanese Man - Chinese Woman and language shift occured in one family namely Chinese Man - Malaynese Woman.

3. The reasons why language shift and language maintenance occured in intermarriage Chinese families are bilingualism in which the man or woman mastered two languages which led to language maintenance, migration in which the women migrate to follow their husband which led to language shift and language maintenance, economic factor dealing with the men and women's occupations which affected them to maintain or to shift their languages, environment where they lived in homogenous or heterogenous ethnic affected them to maintain or to shift their language, demographic factor which made them to use Indonesian 
language, and attitude which might be postive to maintain language or negative to make language shift occured.

\section{REFERENCES}

Bano, K.F. 2010. Characteristics of Language Shift in Two American Hungarian Bilingual

Communities. International Journal of the Sociology of Language $\quad$ 2. 6-18

Bogdan, R.C. \&Biklen, S.K. 1992. Qualitative Research for Education; Introduction to Theory and Methods $2^{\text {nd }}$ edn. Boston: Allyn and Bacon

Burns, R.B. 1995. Introduction to Research Methods. London: Longman Chin, N.B. \& Wigglesworth, G. 2007. Bilingualism: An Advanced Resource Book. New York: Routledge

Conkline, N. \& Lourie, M. 1983. A Host of Tongues: Language Communities in the United States. New York: Free Press. Society.

Conklin, N.F. \&Margareth, A.L. 1983. Multilingualism and Language Change. London: The Free Press Collier Macmillan

Fasold, R. 1984. The sociolinguistics of Society. New york : Basil Blackwell

Masruddin. 2014. Influenced Factors Towards The Language Shift Phenomenon Of Wotunese. Vol 4 No 2. Retrieved at:

http://www.iiste.org/Journals/index.php/RHSS/article/viewFile/10673/11003 on June 2016.

Miles, M.B., M.A. Huberman., \& J. Saldana. 2014. Qualitative Data Analysis: A Methods Sourcebook. USA: Sage.

Putri, R.S., Setiawan, Slamet. 2014. Language Shift and Maintenance among Chinese Community in Surabaya: A Case of Non-Migrant Community. Vol 2 No 2.

Schmid, M.S. 2004. First Language Attrition: Interdisciplinary perspectives on Methodological Issues. Amsterdam: Benjamins 
